\title{
Phytochemicals Screening and Antioxidant Activities of Aqueos Leaves Extract of Euodia ridleyi and Colubrina asiatica
}

\author{
Nik Hairiah Nik Mohamad Ravi ${ }^{1}$, Nor Azila Maskam², Husna Hawa Mohd Hassan ${ }^{3}$, \\ Maryana Mohamad Nor ${ }^{4}$

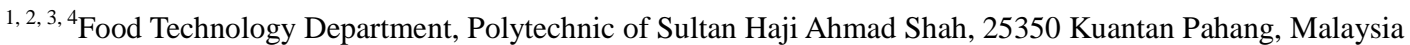

\begin{abstract}
This study was conducted to identify the presence of phenol, flavonoids and antioxidants resulted from the aqueous extracts of the leaves of Euodia ridleyi (Tenggek burung) and Colubrina asiatica (Peria pantai). The established conventional methods were used for quantify the total phenol, flavonoids contents and antioxidant activity. Phytochemicals screening were conducted to determine the presence of flavonoids, tannin, saponin, terpenoid and phenolic content whilst DPPH method were used in determining total antioxidant activities. The positive result obtained from a screening test for both plants as it showed the presence of flavonoids, tannin, saponin, terpenoid and phenolic content. The analysis of total phenolic showed E. ridleyi contains $44.56 \pm 0.35 \mathrm{mgGAE} / \mathrm{g}$ and $20.97 \pm 0.53$ $\mathrm{mgGAE} / \mathrm{g}$ for C. asiatica. The result of total flavonoid showed C. asiatica has contained $1.51 \pm 0.09 \mathrm{mgQE} / \mathrm{g}$ and $0.14 \pm 0.03 \mathrm{mgQE} / \mathrm{g}$ for $\mathrm{E}$. ridleyi. Concentrations of the plant extracts required for $50 \%$ inhibition of DPPH radical scavenging effect $\left(I C_{50}\right)$ were recorded as $5.04 \pm$ 2.17 for E. ridleyi and $5.85 \pm 0.17$ for C. asiatica. Thus, this study is useful in developing plant based antioxidant, which expected to be superior to synthetic antioxidant especially in the development of drugs to treat various diseases.
\end{abstract}

Keywords: Euodia ridleyi, Colubrina asiatica, phytochemicals screening, antioxidant activity, DPPH assay

\section{Introduction}

Medicinal plants have been receiving special attention not only due to their history in folk medicinal but also play an important role in the modern medicine. The herbs have been used as traditional treatments either for preventative or even curative purposes and in addition, a valuable natural resources as potentially safe drugs [Hassawi and Kharma, 2006; Bhat.et al., 2009]. Plants and herbal extracts are considered as important materials in modern medicine, due to their phytochemical and medicinal contents in natural form. According to Rasha Saad et al. 2014, natural drugs is usually used to cure some ailments which may not be treated by conventional medicine.

Over the years, the study of antioxidants as substances that used to fight against the free radicals has attracted the concerns of the public and researchers (Rasha Saad et al. 2014). Yet, as not many research have been conduct for selected herbs (Ayoola et.al, 2008), therefore two types of herbs, namely Euodia ridleyi and Colubrina asiatica were selected in determining their phytochemicals and antioxidant activities through this study.

Euodia ridleyi locally name tenggek burung is traditionally used during confinement period and very helpful in lowering high blood pressure and blood circulation. Colubrina asiatica or peria pantai is also called lather leaf because of its ability to produce lather in water. C. asiatica is eaten with rice after being half-boiled and it is claimed to improve digestion. Traditionally, C. asiatica used in the treatment of headache and body aches, fever and pain reliever, improve digestion, stabilize blood pressure, help control diabetes, as an abortifacient as well as a piscicide and migraine remedy (Saidin,2010).
An antioxidant refer as any substance that, when present at low concentrations significantly delays or prevents oxidation of cell content like proteins, lipids, carbohydrates and DNA( Vivek \& Suraj, 2006). Currently, research on free radical confirms that essential role play by rich food in antioxidant in the prevention of cardiovascular diseases and cancer (Valko et al, 2007) and (Ljubuncic et al, 2005). Synthetic antioxidants such as butylated hydroxyanisole (BHA), butylated hydroxytoluene (BHT), tert-butylhydroquinone (TBHQ) and propyl gallate (PG) widely used in food industries, however have been examined for possible toxicity. Hence, more studies on natural antioxidants derived from plants to replace the synthetic antioxidants. Therefore, the application of natural product like natural antioxidants as food additives not only healthier and safer than synthetic one but also will be more acceptable among modern consumers.

\section{Materials and Methods}

\subsection{Plant Material Preparation}

The leaves of Euodia ridleyi (tenggek burung) and Colubrina asiatica (peria pantai) were obtained fresh from Kampung Pandan 2 and Kampung Padang, Kuantan Pahang. These specimens were then sent to the botanist for confirmatory identification. All samples were washed using tap water and the damaged and disease portions were removed. All chemicals and solvents used were of analytical grade unless otherwise specified.

\subsection{Sample Collection and Extraction}

The plant sample was cut into small pieces and the leaves were dried in a dryer (Protech) at $40^{\circ} \mathrm{C}$ for two weeks, grind (Qingdao Dahua Double Circle), labeled and stored in airtight container for further used. An amount of $50 \mathrm{~g}$ of ground samples was extracted using $250 \mathrm{~mL}$ deionized water. 


\section{International Journal of Science and Research (IJSR) \\ ISSN (Online): 2319-7064 \\ Index Copernicus Value (2013): 6.14 | Impact Factor (2015): 6.391}

The mixture was allowed to stand for 24 hour at $60^{\circ} \mathrm{C}$. The aqueous extract was obtained by filter the mixture through Whatman No. 1 filter paper and used for analysis without further treatment. The extract was kept in Biomedical refrigerator (CHRIST, BETA 1-8 LD plus) (at $-20^{\circ} \mathrm{C}$ ) and freeze dried (Fiocchetti, Sientific Refrigerator) for 8 days.

Percentage yield of extraction (\%) = weight of crude extract in beaker after dried(g) - weight of blank beaker (g) x $100 \%$ Weight of sample in thimble before dried (g)

\subsection{Evaluation of Phytochemicals Screening Test}

The crude extracts of samples were analyzed for the presence of flavonoid, phenolic content, saponins, tannins and terpenoids compounds.

\section{Sample Preparation}

$0.05 \mathrm{~g}$ of sample was weighed using digital balance in $100 \mathrm{ml}$ beaker. Each sample is then diluted with $20 \mathrm{ml}$ with distilled water.

\section{Test for Flavonoids}

A few drop of sample was dropped in the test tube. $5 \mathrm{ml}$ of sodium hydroxide and $1 \mathrm{ml}$ of nitric acid was added into the tube. The test tube was shaken until the yellow coloration disappear, indicates the presence of flavonoids (Ayoola et al, 2008).

\section{Test for Tannins}

A few drops of the sample crude extract are placed in a test tube. $2 \mathrm{ml}$ of distilled water is added. The mixture was shaken before placing into water bath for 5 minutes at $80^{\circ} \mathrm{C}$ to $100^{\circ} \mathrm{C}$. after that, two or three drops of $0.1 \%$ iron (III) chloride was added and observed for brownish green or a blue-black colouration. (Ayoola et al, 2008).

\section{Test for Saponins}

A few drops of the sample crude extract are placed in the test tube. About $5 \mathrm{ml}$ of distilled water was added and shaken vigorously. The formation of stable bubble froth indicates the presences of saponins. (Ayoola et al, 2008).

\section{Test for Terpenoids (Sakowski Test)}

A few drops of the sample crude extract are added with $2 \mathrm{ml}$ of chloroform. Carefully, follow with $3 \mathrm{ml}$ concentrated $\mathrm{H}_{2} \mathrm{SO}_{4}$. A reddish brown colouration indicates the presence of terpenoids. (Ayoola et al, 2008).

\section{Test for Phenolic Content}

A few drops of the sample crude extract are dropped into a test tube. About $2 \mathrm{ml}$ of distilled water were added followed by 2 or 3 drops of $10 \%$ iron (III) chloride solution. The presence of green or blue color indicates the presence of phenolic compounds. (Sabri et al, 2012)

\subsection{Determination of Total Flavonoid Content (TFC)}

About $0.01 \mathrm{~g}$ sample were diluted with distilled water to obtain $0.01 \mathrm{~g} / \mathrm{ml}$ of the sample concentration. Then, $1.0 \mathrm{ml}$ sample was mixed with $4 \mathrm{ml}$ of distilled water and subsequently with $0.3 \mathrm{ml}$ of a NaN03 solution (10\%). After 5 minutes, $0.3 \mathrm{ml} \mathrm{AICI}_{3}$ solution (10\%) was added, followed with $2.0 \mathrm{ml}$ of $\mathrm{NaOH}$ solution (1\%) to the mixture. The sample absorbance was measured at $510 \mathrm{~nm}$ with a UV-Visible spectrophotometer. Distilled water was used as a blank. The total flavonoid concentration in water extract was then calculated from quercetin hydrate (Qu) calibration curve $(0.1-0.5 \mathrm{mg} / \mathrm{ml})$ and expressed as quercetin equivalents $(\mathrm{Qu}) / \mathrm{g}$ of dry extract. Measurements were done in triplicates.

\subsection{Determination of Total Phenolic Content (TPC)}

\section{Principle of method}

Total phenolic content were determined by Follin-Ciocalteau method (Singleton \& Rossi, 1965), based on complex formation of molybdenum-tungsten bleu. The samples were allowed to react with Follin-Ciocalteau's reagent and sodium carbonate solution. The phenolic contents were estimated using a standard curve of gallic acid and expressed as mg of gallic acid equivalents (GAE) / g of extract.

\section{Sample Analysis}

Total phenolic content were measured using the modified Folin-Ciocalteau method (Andrew, 2012). About 0.01g samples were diluted with distilled water to gain $0.01 \mathrm{~g} / \mathrm{ml}$ of the sample concentration. Then $0.4 \mathrm{ml}(400 \mu \mathrm{l})$ was pipette from stock solution into a test tube. After that, $2 \mathrm{ml}$ of $50 \%$ Folin-ciocalteu's Reagent were added into the mixture and vortex for 5 minutes. Next, $4 \mathrm{ml}$ of 5\% Na2CO3 were added and placed the test tube in the dark for 1 hour. After 1 hour, the mixture were measured the absorbance at $765 \mathrm{~nm}$ with a UV-Visible spectrophotometer (Shimadzu, UV-18800) with distilled water as a blank. The total phenolic content was calculated using gallic acid (GA) calibration curve (50-500 $\mathrm{mg} / \mathrm{ml}$ ). Data were expressed as gallic acid equivalents (GA)/g of extracts averaged from 3 measurements. The TPC of samples were calculated based on the equation below:

$$
\mathrm{y}=\mathrm{mx}+\mathrm{c}
$$

Where, $\mathrm{y}=$ absorbance at $765 \mathrm{~nm} ; \mathrm{x}=$ total phenolic content

\subsection{Determination of Antioxidant DPPH assays}

\section{Preparation of Standard Sample and Solution}

The antioxidant activity of plant extracts and the standard was assessed on the basic of free radical scavenging effect of the stable 1,1-diphenyl-2-picrylhydrazyl (DPPH) which is free radical activity by modified method (A. Khalaf et al,2008). The dilute working solutions of the test extracts were prepared in methanolic solution to give the concentration $1 \mathrm{mg} / \mathrm{ml}$.

\section{Preparation of DPPH solution}

The stock of 1,1-diphenyl-2-picrylhydrazyl (DPPH) was prepared. About 0.01g of 1,1-diphenyl-2-picrylhydrazyl $(\mathrm{DPPH})$ was diluted in $250 \mathrm{ml}$ methanol. It was protected from light by covering the volumetric flask with aluminum foil.

\section{DPPH scavenging activity}

DPPH concentration is reduced by the existence of an antioxidant at $517 \mathrm{~nm}$ and the absorption gradually 


\section{International Journal of Science and Research (IJSR) \\ ISSN (Online): 2319-7064 \\ Index Copernicus Value (2013): 6.14 | Impact Factor (2015): 6.391}

disappears with time. The spectrophotometer was used to determine the antioxidant activity. From the dilution of 0.02 $\mathrm{ml}$ of sample was added with $0.8 \mathrm{ml}$ of methanol and $2 \mathrm{ml}$ of DPPH solution. The mixture was shaken using vortex for 30 seconds and leave for 30 minutes in dark condition (Molyneux et al, 2004). The reduction and $\mathrm{IC}_{50}$ were calculated. The free radical scavenging activity (\% inhibition) was calculated using the formula given below:

$\%$ inhibition $=$ (absorbance blank-absorbance sample $) \times 100$

\section{Absorbance blank}

Extract concentration providing 50\% inhibition ( $\left.\mathrm{IC}_{50}\right)$ calculate from the graph plotted of inhibition percentage against extract concentrations.

\section{Results and Discussions}

Yield of samples.

The yield of E. ridleyi and C. asiatica extraction were $25.14 \%$ and $18.37 \%$ (Table 1 ) respectively.

Table 1: The percentage of yield extraction of Euodia ridleyi and C. asiatica

\begin{tabular}{|c|c|}
\hline Samples & Percentage of crude extract (\%) \\
\hline E. ridleyi & $25.14 \pm 0.07$ \\
\hline C. asiatica & $18.37 \pm 0.19$ \\
\hline
\end{tabular}

Phytochemical screening of plant materials

Different phytochemicals test were used to identify the phytochemical present in the samples. According to the result as in Table 2, the screening for phytochemical of the plants studied showed the presence of all phytochemical.

Table 2: Phytochemical Screening of Euodia ridleyi and $C$. asiatica

\begin{tabular}{|c|c|c|c|c|c|}
\hline Samples & Flavonoids & Taninns & Saponins & Terpenoids & $\begin{array}{c}\text { Phenolic } \\
\text { compound }\end{array}$ \\
\hline Euodia ridleyi & ++ & ++ & + & +++ & +++ \\
\hline C. asiatica & ++ & +++ & ++ & +++ & +++ \\
\hline
\end{tabular}

'+++' sign indicates the compunds strongly present, '++' sign indicates moderately present, '+' sign indicates weak present and '-' sign indicates the compounds are absent.

\section{Total Phenolic Contents}

Table 3 showed the result for total phenolic contents found in both plant leaves extraction. It is found that the total phenolic content for E. ridleyi, calculated from the calibration curve $\left(\mathrm{R}^{2}=0.99932\right)$ was $44.56 \pm 0.35 \mathrm{mg}$ GAE/g, higher than C. asiatica extracts with $20.97 \pm 0.53$ $\mathrm{mg}$ GAE/g. The summarized of the results for the extraction of total phenol contents are as below.

Table 3: Total phenolic contents (mgGAE/g) value of E.ridleyi and C. asiatica

\begin{tabular}{|c|c|}
\hline Extract & Phenol contents (mgGAE/g) \\
\hline E.ridleyi & $44.56 \pm 0.35$ \\
\hline C. asiatica & $20.97 \pm 0.53$ \\
\hline
\end{tabular}

\section{Total Flavonoid Contents}

The result for total flavonoid contents of aqueos extraction are shown in Table 4. According to the table, the total flavonoid contents calculated from the calibaration curve $\left(\mathrm{R}^{2}\right.$ $=0.97169$ ) obtained in C. asiatica and E. ridleyi extracts was $1.51 \pm 0.09 \mathrm{mgQE} / \mathrm{g}$ and $0.14 \pm 0.03 \mathrm{mgQE} / \mathrm{g}$ respectively.

Table 4: Total Flavonoid contents (mgQE/g) value of E.ridleyi and C. asiatica

\begin{tabular}{|c|c|}
\hline Extract & Flavonoid contents $(\mathrm{mgQE} / \mathrm{g})$ \\
\hline E.ridleyi & $0.14 \pm 0.03$ \\
\hline C. asiatica & $1.51 \pm 0.09$ \\
\hline
\end{tabular}

\section{Radical scavenging activity assay (DPPH)}

The DPPH analysis is based on the exchange of hydrogen atoms between the antioxidant and the stable DPPH free radical (Blois et al., 1958; Singh et al., 2008). DPPH gives a strong absorption band at $517 \mathrm{~nm}$ in visible region. When the odd electron becomes paired off in the presence of a free radical scavenger, then absorption reduces and the DPPH solution is decolourised from deep violet to light yellow, which is monitored spectrophotometrically. The degree of reduction in absorbance measurement is expressing the radical scavenging (antioxidant) capability of the extract.

The results for aqueous leaves extract obtains in both sample are shown in Table 5. E. ridleyi contains $5.04 \pm 2.17 \mathrm{mg} / \mathrm{ml}$ and $C$. asiatica was $5.85 \pm 0.17 \mathrm{mg} / \mathrm{ml}$, thus, the scavenging activity capacities for both sample were less than BHT (0.19 $\pm 0.01 \mathrm{mg} / \mathrm{ml})$

Table 5: $\mathrm{IC}_{50}(\mathrm{mg} / \mathrm{ml})$ value of $E$. ridleyi, C. asiatica and BHT

\begin{tabular}{|c|c|}
\hline Extract & $\mathrm{DPPH} \mathrm{IC}_{50}(\mathrm{mg} / \mathrm{ml})$ \\
\hline E. ridleyi & $5.04 \pm 2.17^{b}$ \\
\hline C. asiatica & $5.85 \pm 0.17^{b}$ \\
\hline $\mathrm{BHT}$ & $0.19 \pm 0.01^{a}$ \\
\hline
\end{tabular}

\section{Conclusion}

On basis of the results obtained in the present studies, it was concluded that E. ridleyi and C. asiatica extract contains of flavonoid, tannin, phenol content, terpenoid and saponin. In addition, the TPC of E. ridleyi (44.56 \pm 0.35$)$ was higher than C. asiatica $(20.97 \pm 0.53)$ but $C$. asiatica $(1.51 \pm 0.09)$ contains higher in TFC than E. ridleyi $(0.14 \pm 0.03)$. Not all phytochemical are responsible for the antioxidant activity. In other words that even if the plant tested positive for most phytochemical, it could not show the highest antioxidant activity. Further studies are needed for the isolation and identification of bioactive compounds responsible for antioxidant activity.

\section{Acknowledgements}

The authors express gratitude to Department of Food Technology, Polytechnic of Sultan Haji Ahmad Shah and JPP to the grant FRGS/1/2014/STWN03/JPP/03/02 for the financial support.

\section{References}

[1] Andrew Waterhouse. (2012). Folin-Ciocalteau Micro Method for Total Phenol in Wine.

[2] http://waterhouse.ucdavis.edu/faqs/folin-ciocalteau-mic ro-method-for-total-phenol-in-wine. [01 June 2015] 
[3] Ayoola G.A., Coker H.A.B., Adesegun S.A., Adepoju-Bello A.A., Obaweya K., Ezennia E.C., Atangbayila T.O. (2008). Phytochemical Screening and Antioxidant Activities of Some Selected Medicinal Plants Used for Malaria Therapy in Southwestern Nigeria. Tropical Journal of Pharmaceutical Research 7 (3): 1019-1024

[4] Azizah, O., Nor J.M., Nurul S.I. and Sui K. C. (2014). Phenolics, flavonoids content and antioxidant activities of 4 Malaysian herbal plants. International Food Research Journal 21(2): 759-766.

[5] Blois MS. (1985). Antioxidant determination by the use of a stable free radical. Nature, 29:1199-1200.

[6] Dhia Hassawi and Abeer Kharma. (2006). Antimicrobial Activity of Some Medicinal Plants Against Candida albicans. Journal of Biological Sciences 6 (1): 109-114.

[7] Huang, D-J., Ou, B-X. And Prior, R.L. (2005). The chemistry behind antioxidant capacity assays. Journal of Agricultural and Food Chemistry 53:1841-1856.

[8] Khalaf A. N., Ashok K. S., Atif O., Zaha A., Husni F.(2008). Antioxidant Activity of Some Common Plants, Turk J Biol 32:51-55.

[9] Ljubuncic P., Portnaya I., Cogan U., Azaizeh H., Bomzon A. (2005). Antioxidant activity of Crataegus aronia aqueous extract used in traditional Arab medicine. J Ethnopharmacol 2005; 101:153.

[10] Molyneux, P. (2004). The use of the stable free radical diphenylpicrylhydrazyl (DPPH) for estimating antioxidant activity. Songklanakarin J. Sci. Technol. 26(2): 211-219.

[11] Om P. Sharma and Tej K. Bhat. (2009). DPPH antioxidant assay revisited. Food Chemistry. Vol 113, Issue 4, Pages 1202-1205.

[12] Rasha S., Tan P., Jiyauddin K., Li W., Sadia S, Junainah A.H. (2014). Phytochemical Screening And Antioxidant Activity Of Different Parts From Five Malaysian Herbs. International Journal of Science and Technology. Vol. 19(2), 1336-1347.

[13] Sabri F.Z., Belarbi M., Sabri S., Alsayadi M.S.(2012). Phytochemical Screening and identification of some compounds from Mallow. J. Nat. Prod. Plant Resource. 2 (4):512-516.

[14] Saidin, I. (2010). Sayuran tradisional ulam dan penyedap rasa. 147 p. Bangi: UKM.

[15] Shukri M., Alan C., Noorzuraini S.A.R. (2011), Polyphenols and Antioxidant Activities of Selected Traditional Vegetables. J. Trop. Agric. And Fd. Sc. 39(1); 69-83.

[16] Singh R., Singh N., Saini B.S., Rao H.S. (2008). Invitro antioxidant activity of pet ether extract of black pepper. Ind J Pharmacol 40:147-151.

[17] Singleton C.P, Rossi J.A. (1965). Colorimetry of Total Phenolics with Phosphomolybdic-Phosphotungstic Acid Reagents. Am J Enol Vitic 16:144.

[18] Valko M., Leibfritz D., Moncol J., Cronin M.T.D, Mazur M., Telser J. (2007). Free radicals and antioxidants in normal physiological functions and human disease. Inter J Biochem Cell Biol 39:44.

[19] Vivek K. G. and Surendra K. S. (2006). Plants as natural antioxidants. Natural Product Radiance Vol. 5(4), pp. 326-334. 